\title{
TEORETSKI KONCEPTI O ČUSTVIH ${ }^{D_{r} \text { Nives }}$ TEORETSKI KONCEPTI O CUSTVIH Lǐem, Teoretski konstrukti kot okvir za razumevanje in vzgojo čustev \\ Filozofska \\ fakulteta Univerze \\ v Ljubljani
}

\section{POVZETEK}

$V$ besedilu avtorica prikazuje razvoj teoretskih konceptov o čustvih, ki so pomembni za vzgojo in izobraževanje. Ugotavlja, da so se teorije dopolnjevale in razvijale. Podrobneje prikaže Galatijevo triadno taksonomijo, ki je sestavljena iz evolucionistično-funkcionalističnih teorijo čustvih, kognitivističnih teorij in iz skupine komunikacijsko sociokonstruktivističnih teorij. Tri skupine teoretskih pogledov poudarijo proces adaptacije, komunikacije in kognicije v povezavi z. emocijani. Omenjena tri podroçja so pomembna za vzgojo in izobraževanje, saj teoretski konstrukti lahko služijo za razumevanje čustev, za sporazunevanje o istvih in za oblikovanje modelov, s katerimi čustva vzgajamo.

Ključne besede: čustvenost, inteligenca, teorija, taksonomija, izobraževanje, vzgoja

\section{UVOD}

Čustvenost je dimenzija človekovega bivanja, o kateri so začeli intenzivneje govoriti in pisati $v$ zadnjih desetih letih. V preteklosti se je s čustvi ukvarjala filozofija, tako da $v$ sodobnosti razlikujejo med zgodovino filozofije čustev (Abbagnano, 2002) in sodobno filozofijo čustey, kasneje je čustva raziskovala psihologija in psihoanaliza, ki je postavila čustva $v$ središče svoje pozornosti. O čustvih govorijo splošna prepričanja med ljudmi, s čustvi se ukvarja sociologija, ki razvija svoje raziskave $\mathrm{v}$ okviru sociologije čustev (prim. Šadl, 1999), čustva so tudi predmet raziskav $v$ nevrofiziologiji in nevropsihologiji (prim. Oliverio, 2001), V okviru psihologije se razvija poddisciplina psihologija čustev, znanstveniki se družijo $v$ mednarodni organizaciji za raziskovanje čustev (International Society for Research on Emotion, ISRE). Za čustva se zanimajo raziskovalci in konstruktorji umetne inteli- gence, kjer se sprašujejo: ali so lahko naprave inteligentne brez emocij (prim. Minsky, 2003).

$\mathrm{V}$ filmski industriji se proces zanimanja za emocije pokaže pri kreaciji junaka Date $v$ Zvezdnih stezah, ki v začetnih nadaljevanjih še nima čustev in deluje kot robot, nato pa mu v pozitronske
Čustva so tako ali drugače prednet mnogih znanstvenih aisciplin. možgane vstavijo čip za čustva. Za čustva se zanimajo vojaki in duhovniki, starši in ljubimci, pesniki in menedžerji, arhitekti umetne inteligence in vzgojitelji, Z vzgojo čustev se ukvarjata pedagogika in andragogika. V prispevku bomo analizirali različne pristope $\mathrm{k}$ opredeljevanju čustev, ugotavljali elemente čustvenega življenja, ki omogočajo medsebojno vplivanje, socializacijo in individualizacijo čustev ter prikazali nekatere teoretske koncepte čustev, ki so pomembni za vzgojo. 


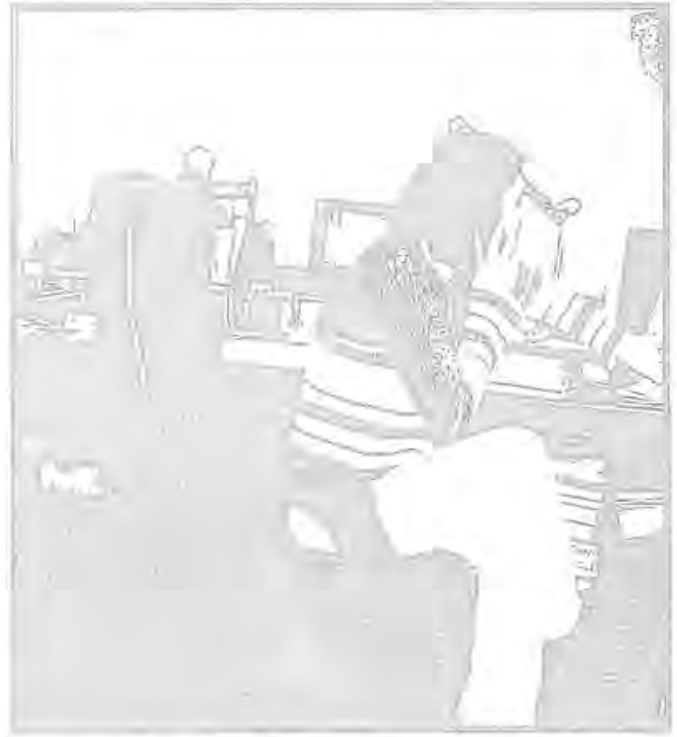

\section{TEORIJE O ČUSTVIH}

Kronološko gledano so se teorije o čustvih spreminjale, razvijale in dopolnjevale. Plutchik (1980) razdeli teorije o čustvih v dva sklopa, in sicer v evolucionistične teorije, kjer velja za začetnika Darwin s svojim delom Izražanje čustev pri človeku in živalih iz leta 1872 , in psihofiziološke teorije, kjer je najvidnejši avtor James. Štirinajst let pozneje, 1994, je Plutchik prikazal nekoliko drugačno klasifikacijo teorij o čustvih. Razdelil jih je v štiri večje skupine:

- motivacijske teorije, kjer je osrednji odnos med emocijo in motivacijo,

- kognitivne teorije, kjer je osrednjega pomena proces kognitivnega ovrednotenja dražljaja,

- psihoanalitične teorije, ki izhajajo iz Freudove psihoanalize,
- evolucionistične teorije, ki prikazujejo emocijo kot sad biološke evolucije (Plutchik, 1995).

Cornellius (1996), ki v svojem delu prikaže zgodovino raziskovanja emocij od začetkov psihologije, združi teoretske poglede $v$ štiri osnovne perspektive. Kronološko postavi kot najstarejšo darvinistično perspektivo, ki sloni na teoriji biološke evolucije, sledi ji Jamesova perspektiva, ki sloni na raziskavah somatskih reakcij - telesnih odzivov, značilnih za čustva. V šestdesetih letih se je razvila kognitivistična perspektiva, ki se zanima za povezavo med kognicijo in emocijo, v osemdesetih letih se srečamo s konstruktivistično paradigmo, ki je poglobljeno razčlenjevala socialne vidike čustev in $v$ svojih skrajnostih razlagala čustva zgolj kot produkt pravil vedenja in sociokulturne komunikacije.

\section{GALATIJEVA TRIADNA TAKSONOMIJA}

Italijanski profesor psihologije čustev Dario Galati $(1992,2002)$ predlaga svojo tipologijo, ki jo imenuje triadna taksonomija. Njegova tipologija je sintetizirana in omogoča opazovanje razlik med tremi zornimi koti raziskovanja čustev. Avtor ne vključuje psihoanalitičnih pogledov, ker so se razvili predvsem klinični aspekti s posebnim zanimanjem za patološko manifestacijo čustev. $\mathrm{V}$ nadaljevanju besedila bomo podrobneje predstavili posamezne sklope triade.

Prvi del Galatijeve triadne taksonomije predstavlja evolucionistično-funkcionalistična paradigma, ki izpostavi, da čustva služijo osebku za njegovo prilagajanje okolju. Drugi del triade predstavlja kognitivistična paradigma, ki ugotavlja, da čustva služijo osebku za spoznavanje. Kognitivisti prepoznajo osrednjo vlogo kognitivnih procesov v genezi čustev. Tretji sklop triade je konstruktivistično-socialna paradigma, ki prikaže, da čustva služijo za komuniciranje s svetom. 
EVOLUCIONISTIČNO-FUNKCIONALISTIČNE TEORIJE posvečajo osrednjo pozornost odnosu med biološkim in mentalnim tako pri Darwinu kot pri Jamesu, ki ga štejejo za začetnika psihološkega funkcionalizma. Galati (2002) ga označi kot "podružnico evolucionizma". Biološke, mentalne in socialne fenomene želijo pojasniti na znanstven način, prikazati razvojnost pojavov, pri čemer se ne želijo posluževati metafizičnih principov. Skupno izhodišče teorijam $v$ tej skupini je predpostavka, da so se mentalne strukture razvile tako, da se organizmi prilagodijo okolju in si zagotovijo zadovoljitev svojih potreb, Po teh teorijah so custva s svojimi mentalnimi in somatskimi elementi povezava med biološkim in mentalnim življenjem, so "vmesni člen" med telesom in umom. So prirojena in univerzalna, njihova funkcija je $\mathrm{v}$ prilagajanju okolju.

Evolucionistične teorije obravnavajo ěustva kot rezultat biološke evolucije, zato jih $v$ raziskovanju zanimajo univerzalne prirojene oblike odgovorov.

Zanimajo jih prirojeni vedenjski aspekti in fiziološke modifikacije, zgolj obrobno je njihovo zanimanje za mentalne aspekte in individualno doživljanje ěustev. Kar je razumljivo, saj pojmujejo čustva kot modaliteto odgovorov, $\mathrm{ki}$ so se razvili $\mathrm{z}$ izkušnjami vrste, ne pa z izkušnjami posameznika. Na tej točki bi lahko iskali povezavo s strukturo arhetipov v človekovem nezavednem, kot jih je prikazal Jung (Trevi, Innamorati, 2000). Mentalni procesi, ki zanimajo raziskovalce $\mathrm{v}$ okviru evolucionistično-funkcionalističnih teorij, so predvsem spomin in obdelava informacij stimulusa, $\mathrm{ki}$ je genetsko pogojena in nezavedna. Osnovno spoznanje teorij iz te skupine lahko strnemo $\mathrm{v}$ ugotovitev, da so čustva prirojena in univerzalna ter imajo funkeijo adaptacije.
V KOGNITIVISTIČNI perspektivi je osrednje zanimanje namenjeno kognitivnim vidikom čustev. Ti vključujejo proces mentalne obdelave informacije, ki se začne s procesom aktivacije v neki situaciji, ki je za osebek nova in po njegovi presoji pomembna ter predstavlja posamezniku naSo čustva dediščina evolucije? por zá reorientacijo.

V tej skupini teorij o čustvih ločijo dve podskupini, in sicer:

- aktivacijsko kognitivne teorije in

- teorije ocene ("appraisal").

Aktivacijsko kognitivne teorije, od katerih je najbolj znana bifaktorska teorija, prikazujejo čustva $\mathrm{y}$ povezavi z dvema dejavnikoma. To sta fiziološki stimulus in interpretacija stimulusa. Dispozicija za razvoj čustva je fiziološki aktivator, ki npr, povzroči pospešeno bitje srca. Naslednja faza je kognitivna ocena stimulusa. Posameznik interpretira pospešeno bitje srca $\mathrm{z}$ dejstvom, da je tekel po stopnicah. Ker ima razlago za pospešen utrip, se čustvo ne razvije. Če pa za pospešen utrip nima razlage, se razvije čustvo.

Za nastanek čustev sta torej potrebna dva dejavnika: aktivator in kognitivna atribucija. Najbolj znan preizkus, s katerim potrjujejo bifaktorsko aktivacijsko kognitivno teori-


jo, sta opravila Schacther in Singer (1962, v Galati, 2002). V preizkus je bilo vključenih 200 udeležencev. Rekli so jim, da preizkušajo vpliv vitaminov na vidno zaznavanje. Udeležence so razdelili v dve skupini. Prvi so vbrizgali epinefrin, ki vpliva na zviševanje krvnega tlaka in utripa srca ter pospeši dihanje, druga skupina je dobila placebo. Nato so obe skupini razdelili $v$ tri podskupine. Prvi podskupini so povedali, da so dobili epinefrin in kakšne učinke lahko 


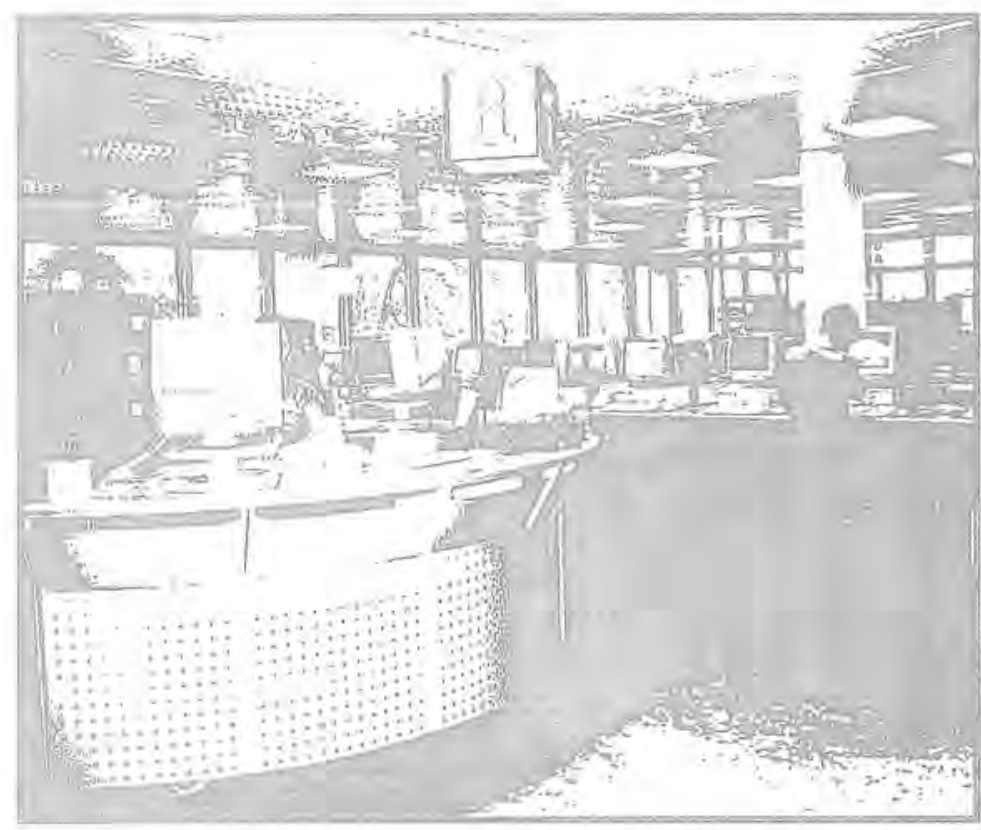

pričakujejo, drugi podskupini so dali napačne informacije o pričakovanih učinkih. Ljudem so rekli, da bodo čutili težke noge in rahel glavobol. Tretji podskupini niso dali nobenih pojasnil. Vse podskupine so nato doživele situacije, ki v običajnih razmerah povzročijo veselje, evforijo (zabavali so jih klovni) ali pa jezo (izpolnjevati so morali vprašalnik $\mathrm{z}$ indiskretnimi in agresivnimi vprašanji).

\section{Ali čustvo nastane zaradi posebnega odnosa cloveka do okolja?}

Rezultati raziskave so potrdili pričakovanja. Čustveni odzivi $\mathrm{v}$ skupini, ki je prejela placebo, so bili šibkejši kot v skupini, ki je prejela epinefrin. Osebe, ki so bile napačno informirane ali pa niso bile informirane, so bile bolj čustveno vznemirjene kot osebe, ki so bile ustrezno informirane. Osebe, ki so dobile placebo in niso bile informirane, so bile (po njihovi subjektivni presoji) bolj čustveno vznemirjene kot osebe, ki so prejele epinefrin in ustrezno informacijo. V obeh skupinah raziskovalci niso pričakovali razlik $\mathrm{v}$ emocionalnem odgovoru, ker je pri obeh manjkal eden od potrebnih faktorjev. Bodisi da ni bilo fiziološkega aktivatorja (dobili so placebo) bodisi, da so lahko ustrezno interpretirali spremembe (kognitivno pripisovanje). Raziskovalci so razlike pripisali dejavnikom med raziskavo.

Kritiki očitajo bifaktorski teoriji pomanjkljivosti, saj so bili preizkusi opravljeni laboratorijsko. Aktivator $\mathrm{v}$ realnem življenju ni injicirana snov, temveč dogodek ali situacija. Poleg tega tudi ponovitve raziskave niso dale enakih rezultatov.

Shemo sta dopolnila Pribam (1967, 1970, 1984) in Mandler (1975, v Galati, 2002). Pojasnila sta, zakaj nastane fiziološka reakcija v realnem življenju. Ta nastane zaradi oviranja načrta, ki je motiviran. Ovire, ki nastanejo zaradi sprememb $v$ notranjem ali zunanjem okolju, povzročijo aktivacijo avtonomnega živčnega sistema (predvsem simpaticus) (prim. Pribam, 1984, Legrenzi, 2002). Fiziološke modifikacije spodbudijo kognitivne procese, ti raziščejo, kaj se je zgodilo. Pribam opisuje razliko med motivacijo in emocijo. Motivacija se nanaša na dispozicijo o subjektu, ki deluje, da bi zadovoljil svoje potrebe in uresničil tendenco po nekem vedenju, ne da bi ga kdo oviral na poti do cilja. Emocija se razlikuje od motivacije, ker se aktivira tedaj, ko vedenje, ki je motivirano, naleti na oviro. Pribam je s svojo razlago uvedel manjkajoči člen: v življenju namreč ni injiciranega epinefrina, temveč subjekt zazna ovire v programu vedenja. Tedaj se vzbudi fiziološka reakcija, posledica te je iskanje novih informacij, da bi subjekt oviro odstranil.

Emocija je odvisna od potreb organizma in informacije, ki je potrebna za zadovoljitev potrebe. Če je situacija nova in so potrebne informacije manjše od že znanih informacij, bo nastala fiziološka reakcija. Če je potrebna informacija manjša od tiste, ki jo organizem že ima, ko se znajde v novi situaciji, se bo razvila emocija. 
Druga skupina teorij o čustvih je t. i. torija ocene ("appraisal"), ki izpostavi tezo, da je pomen stimulusa vedno pripisan, je vedno sad vrednotenja, ocene stimulusa. Iz te skupine teorij je znana Lazarusova teorija (Smith, Lazarus, 1993), ki jo imenujejo tudi relacijska in motivacijska kognitivna teorija čustev (Legrenzi, 2002). Ocena dogodka, stimulusa, se vedno povezuje $\mathrm{z}$ motivacijo posameznika, ki se dogaja $\mathrm{v}$ odnosu $\mathrm{z}$ možnostmi za zadovoljitev potreb v okolju. Čustvo nastane zaradi relacije do okolja.

Evolucionistično funkcionalistične teorije osvetlijo predvsem funkeijo ěustev za adaptacijo okolju ter prirojenost in univerzalost čustev, kognitivistične teorije dajejo osrednjo vlogo kognitivnim procesom pri oblikovanju čustev. Vloga čustev ni $v$ prilagajanju, marveč $v$ spoznavanju sveta. Lazarusova teorija nakazuje tudi pomen okolja, ki ga vidneje upoštevajo komunikacijske in sociokonstruktivistične teorije čustev, po katerih čustva služijo predvsem za komunikacijo z okoljem.

\section{KOMUNIKACIJSKA IN SOCIOKON-} STRUKTIVISTIČNA PERSPEKTIVA razlaga čustvo kot instrument za socialno interakcijo. $V$ to skupino so uvrščene raziskave in teorije, $\mathrm{ki}$ pripisujejo pomembno vlogo odnosnemu in komunikacijskemu vidiku čustev. To ne pomeni, da ostali dve skupini zanikata pomen odnosov $v$ genezi čustev. Obe ga upoštevata, vendar pa ga ne postavljata na prvo mesto, temveč ga opisujeta kot sekundarno dogajanje, ki je posledica funkcije adaptacije, kar je bilo že Darwinovo mnenje, ali pa izhaja iz procesov vrednotenja stimulusov.

Za komunikacijsko in sociokonstruktivistično perspektivo so čustva instrument komunikacije in jih pojasnjujejo s kontekstom, kjer čustva nastanejo. Glede na kontekst ločijo dve skupini teorij. Tiste, ki omejujejo kon- tekst na interpersonalne odnose, imenujejo odnosne teorije in se nanašajo na skupine, $v$ katerih subjekt vzpostavlja čustvene odnose. Socialne teorije pa so tiste, $\mathrm{ki}$ opredelijo kontekst kot širok socialni prostor, $v$ katerem je subjekt umeščen. Na čustva vpliva družba s svojimi normami, vrednotami in kulČustvo kot instrument za socialno komunikacijo. turo. V skupini odnosnih (relacijskih) teorij naletimo na avtorje: Bowlby, Stern, Spitz, M. Klein, Winnicott in Trevarthen.

Trevarthen (1990) v komunikacijski teoriji čustev pokaže na čustva, ki niso biološka pulzija in tudi ne posledica kognitivne obdelave informacij ter visceralnih sprememb, temveč so osnova za vzpostavitev (čustvenega) odnosa med otrokom in materjo, v katerem otrok zori v svoji komunikacijski inteligenci, $v$ svojem zanimanju za druge objekte in $\mathrm{v}$ svoji sposobnosti oblikovanja sodelujočih odnosov. Človek ima v svojem bistvu potrebo po komunikaciji $\mathrm{z}$ drugim človekom in to mu omogočijo čustva. Custva so torej prirojeni instrumenti za komunikacijo. Novorojenček je že pripravljen, da sodeluje v dialogu, vendar čustva ne ostanejo na ravni, kakršna je bila ob rojstvu. Čustva se razvijajo in so lahko kasneje aktivirana tudi $\mathrm{z}$ objekti, s katerimi ne komuniciramo neposredno.

Trevarthen (prav tam) razdeli čustva $v$ tri skupine, glede na stimuluse, ki čustva aktivirajo.

Etična čustva so aktivirana z intersubjektivnimi stimulusi, to je $v$ komunikaciji z ljudmi, estetska čustva so aktivirana z objektivnimi stimulusi, to je $v$ komunikaciji z objekti, avtotelična čustva so vase usmerjena čustva in so aktivirana $z$ internimi stimulusi.

Učenje (doživetja, izkušnje) vpliva na čustva, vendar jih ne ustvarja. Struktura čustev je prirojena, podobno kot struktura jezika. Komunikacijska teorija podobno kot evolucijske teorije predstavi čustva kot prirojena, ki se 
kasneje razvijajo in spodbujajo kognitivni in socialni razvoj. Individuum ne kreira svojih čustev iz nič, temveč iz prirojene osnove. Na tem mestu bi lahko povezali komunikacijske teorije čustev s koncepti temperamenta.

\section{Učenje vpliva na custva, vendar jih} ne ustvarja.

Komunikacija je osrednja tudi v "ekološko vedenjski" teoriji (A. Fridlund), ki priznava pri genezi čustev le delček vpliva genetskim dejavnikom, največji vpliv imata okolje in socialna komunikacija. Čustva so opredeljena s kulturnim kontekstom, prirojene so le tendence, ostalo razvijemo $\mathrm{z}$ učenjem.

"Dinamične" in "sociointerakcijske" teorije (Alan Fogel, 2002, v Barrett, 2002, Dickson et al., 2002, Camras, 1992) zavračajo tezo, da so nekatera osnovna čustva vsem prirojena in se iz njih razvijejo kompleksnejša čustva. Emocija ni nekaj danega, ki se naknadno aktivira z različnimi stimulusi (aktivatorji). Emocija je povsod prisotna in kontinuirana. Ljudje smo vedno čustveni. Spreminja se intenzivnost našega doživljanja, tako da so nekatera čustva bolj vidna, druga manj. Čustva so del procesa človekovih interakcij s svetom, s socialnim kontekstom in ne obstajajo izven interaktivnega procesa, konstruirajo se $v$ interaktivnem procesu. Čustvo je sistem, ki se sam organizira v odnosu do interakcije posameznika $\mathrm{z}$ okoljem. Emocija je dinamična sinteza elementov.

"Konstruktivistična" paradigma čustev (Averill, 1999, Harre, 1986) je utemeljena na filozofskih in antropoloških teorijah. Želijo prikazati kulturno variabilnost emocij.

\section{Čustva so kom- pleksni fenomeni, sestavljeni iz več komponent.}

Če sta Trevarthen in Fogel v temelje čustev še postavljala biološko komponento, pa konstruktivizem predstavi čustva kot socialni fenomen brez sledi biološkosti. Vse je pridobljeno, nič ni prirojeno, čustva so kodeks socialnega vedenja, ki si ga pridobimo $\mathrm{z}$ vzgojo in vsakemu predpiše, kako naj se vede. Averil (1999) zapiše, da jeza ni prirojeno čustvo, ki ima namen, da poskrbi za preživetje subjekta, temveč je shema, ki pokaže subjektu, kaj naj stori v določenih okoliščinah, npr. ko so njegove pravice kršene. Jeza je predstopnja vedenja, ki subjektu "narekuje" vedenje. In nadaljuje, da ni samo pojavnost, ampak tudi intenzivnost čustev, uravnavana $z$ normami in načini izražanja.

Teoretske perspektive postavljajo različne elemente kot najpomembnejše, vse pa ugotavljajo, da so čustva kompleksni fenomeni, sestavljeni iz več komponent. Averill (1999) jih imenuje večkomponentni fenomeni in sindromi, sestavljeni iz različnih elementov, $\mathrm{ki}$ delujejo $\mathrm{v}$ ne vedno enakih sekvencah. Zaporedje ni vedno enako "predpisano".

Elementi $v$ konstruktivističnem modelu emocij so:

- kognitivna ocena, ki je utemeljena na vzgoji in prek katere si oblikujemo načine vrednotenja, sledijo ji

- ekspresivna reakcija,

- fiziološka reakcija,

- instrumentalno vedenje, ki ga izbiramo in je naučeno, ter

- subjektivni občutki.

$\mathrm{Za}$ vse elemente iščejo razlago $\mathrm{v}$ socialnem učenju.

Ocena je odvisna od socialnih in osebnih norm. Posameznik se sprašuje, ali je vedenje primerno pričakovanjem. Če ni primerno, izbere popravke vedenja glede na socialne norme. Sprašuje se tudi, ali odgovori sledijo osebnim normam. Če odgovori niso ustrezni, 
popravi svoje vedenje glede na svoje osebne norme. Proces ocenjevanja ne sloni na biološki vrednosti stimulusov, ne zgodi se samodejno, temveč sloni na pripisovanju pomenov, ki izhajajo iz sistema vrednot in norm kot dela sociokulturnega konteksta.

Konstruktivisti so manj raziskovali fiziološke vidike in subjektivne občutke, ker jih je težje interpretirati s termini socialnega učenja.

\section{ZAKLJUČKI}

Za vzgojo čustev so zanimive tri teme, ki se povezujejo s področjem čustev: adaptacija (prilagajanje), komunikacija in kognicija. Vse tri so razvile svoje teorije čustev; njihova značilnost je, da nobena ne zanika kompleksnosti čustev, ampak vsaka poudari posamezni element.

Evolucionistično-funkcionalistična perspektiva poudari, da so čustva prirojena, so del vrste (species), se različno aktivirajo in so povezana bolj s spominom vrste kot s spominom posameznika. Primarno ima vsak človek omejeno število osnovnih (primarnih) čustev, ki jih štejejo kot modaliteto večkomponentnih, prilagodljivih se odgovorov. Primarna čustva so dokazovali s študijem obraznih gibov (vidiki facialne ekspresije), ki so najdostopnejši za empirično raziskovanje. Raziskovalci iz te skupine skušajo dokazati univerzalnost čustev in neodvisnost čustev od kulture.

Kognitivna ocena, ki je bila postranskega pomena $v$ evolucionističnih in funkcionalističnih teorijah, postane osrednja tema raziskav kognitivistične paradigme, ki se deli v dve podskupini. Aktivacijsko kognitivna skupina pripisuje vzrok za nastanek čustev stimulusu, druga pa pripiše vzrok za nastanek čustev procesu ocene stimulusa. Pri obeh so kognitivni procesi na prvem mestu, tako se npr. jeza ne more razviti, če niso razvite sposobnosti atribucije.
V kognitivistični perspektivi je bil vidik komunikacije postranskega pomena glede na vidik ocene, apercepcije. Komunikacijski vidik postane osrednji v konstruktivističnih teorijah. Emocije so instrument komunikacije, aktualizirajo komunikacijsko namero (Galati, 2002, str. 298), ki se uresniči v predverbalni obliki jezika ( $\mathrm{ki}$ je pred besedno obliko), ki jo uporabljata mati in otrok $\mathrm{v}$ prvi fazi otrokovega razvoja, in v verbalni obliki jezika. Čustva vzpostavijo odnos. Bistvo čustva je komunikacija, cilj čustev je vzpostavljanje odnosov z drugimi, ki se uresničujejo v mikrookolju družine in prijateljstev ter v makrookolju družbe. Tako kot jezik in komunikacija so tudi čustva navezana na učenje (čustva se razvijajo $\mathrm{v}$ konvencionalnost in konsenzualnost). Custva so socialni konstrukti in so del kulturnega konteksta.

Za vzgojo ostaja še vedno odprto vprašanje, katera od omenjenih teorij je uporabnejša pri

Tri različne perspektive, trije različni poudarki. Nobene paradigme ni mogoče potrditi ali zavreči $v$ celoti. Nove paradigme se oblikujejo, ko stare ne zadoščajo več za razlago nekega pojava. Vsaka paradigma vsebuje nastavke za naslednje modele in interpretacije. Če je časovno zadnji model konstruktivističen, ne pomeni, da je edini "pravi". Kot opozarjata Guba in Lincoln (1994), je nevarnost raziskovanja $v$ tem, da se raziskovalci ujamejo v "novo resnico". Tudi pri raziskovanju čustev velja, da se morajo raziskovalci vedno znova spraševati o kritičnih mestih svojega modela, o pomanjkljivostih metod in pristopov $\mathrm{k}$ raziskovanju. Če imajo raziskovalci razkošje, da svoje modele dopolnjujejo, je strokovnjakom $\mathrm{v}$ praksi težje, saj morajo $\mathrm{v}$ vsaki vzgojno-izobraževalni situaciji odreagirati, delovati. Katero paradigmo naj tedaj uporabijo? 
Čustva so temelj

medsebojnih

odnosov. intencionalni vzgoji in $s$ katero lahko razložimo pojave $v$ funkcionalni vzgoji.

Shematično lahko prikažemo zanimanja različnih področij za čustva na naslednji način:
Custva niso samo predmet akademskega zanimanja, kot bi morda sodili po raziskovalnem zanimanju. Velik razmah raziskovanja ěustev odseva pomen, ki ga ima čustveno življenje za posameznika in skupnost. Razvila so se poimenovanja, npr: ěustvena

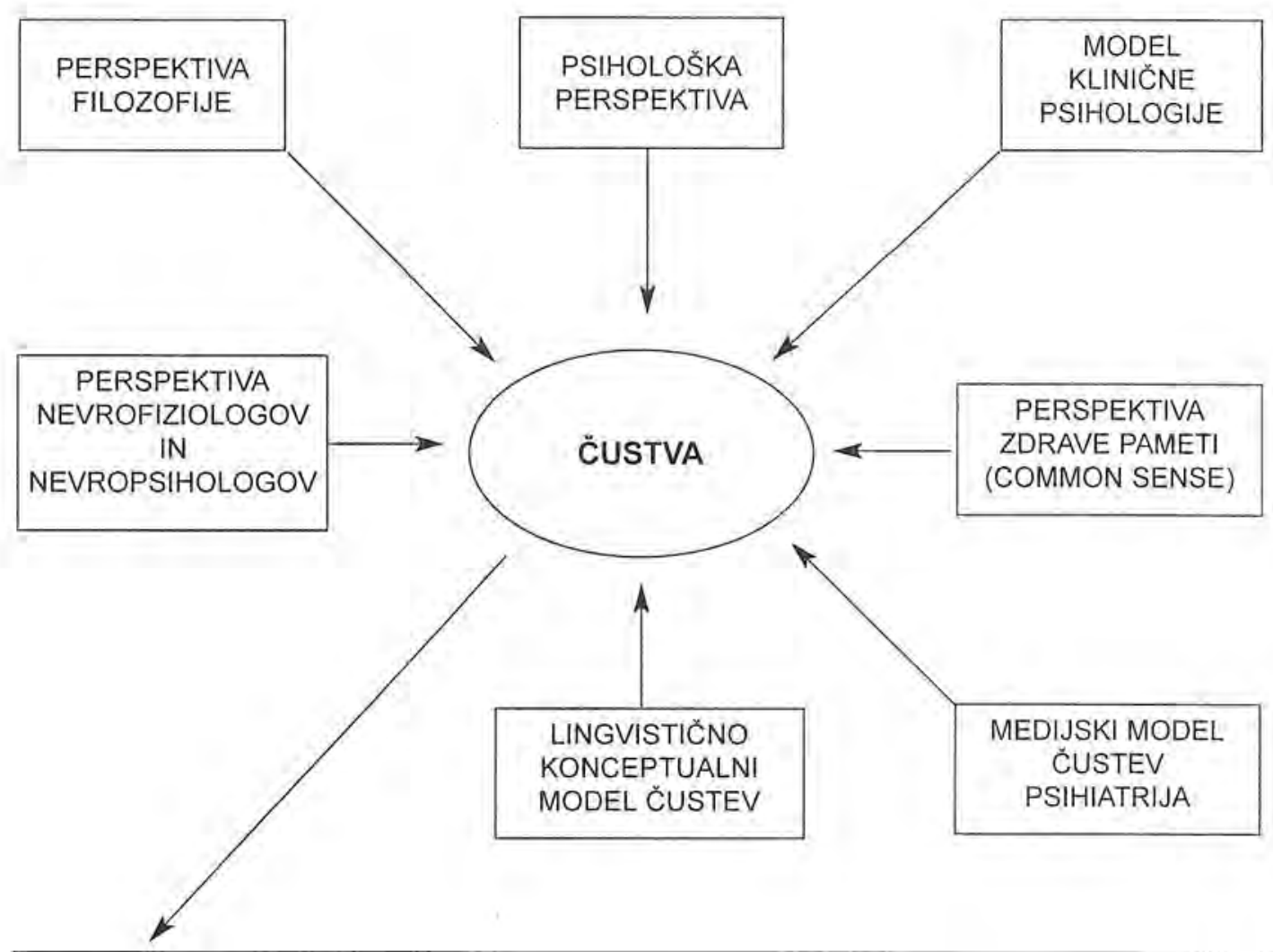

\section{Koga zanimajo čustva?}

Arhitekte umetne inteligence, psihologe, zdravnike, pisatelje, voditelje zabavnih oddaj, menedžerje, vzgojitelje, učitelje, pedagoge, andragoge, politike, starše in ljubimce, vojake in duhovnike, novinarje...

\section{KAR ČUTIŠ, LAHKO VZGAJAŠ?}


inteligenca (prim. Avsec, Pečjak, 2003) in čustvena pismenost, razvoj čustvene inteligence in razvoj čustvene pismenosti. Vedno jasneje postaja, da lahko človek razume sebe in druge, če razume svoja čustva, ki ga vodijo v njemu lastna vedenja. Teoretski konstrukti, ki smo jih prikazali, lahko služijo za razumevanje čustev in sporazumevanje o čustvih.

Čustva so namreč temelj medsebojnih odnosov, ki bistveno določajo kakovost posameznikovega življenja na različnih področjih. Italijanski psihiater Pasini (2001), ki vodi družinske terapije na območju, kjer je veliko družinskih podjetij, je v raziskavi ugotovil, da $v$ tistih družinah, ki imajo funkcionalne medsebojne odnose, cveti tudi posel y podjetju. Zapisal je, da je tedaj podjetje ekonomski stroj, ki deluje kot trenirano telo.

Odpira se nam novo vprašanje, kako čustva delujejo. Ni pomembno, da svoja čustva prepoznavamo, ampak da znamo z njimi tudi upravljati.

\section{LITERATURA:}

Abbagnano, N. (2002). Storia filosofica delle emozioni. V Galati, D. Prospettive sulle emozioni e teorie del soggetto. Torino: Bollati Boringhieri.

Ammaniti, M., Dazzi, N. (ur.) Affetti. Natura e sviluppo delle relazioni interpersonahi. Roma, Bari: Laterza.

Averill, J. R. (1999). Creativity in the Domain of Emotion. V Dalgleish, T., Power, M. J. (ur.) Handbook of Cognition and Emotion. New York: Wiley \& Sons.

Avsec, A., Pečjak, S. (2003). Emocionalna inteligentnost kot kognitivno-emocionalna sposobnost. Psihološki obzorja, 12, st. 2, str. 35-49.

Barrett, K. (ur) (2002). New Directions in Child Development: Emotion and Communication.

Cornellius, R. (1996), The Science of Emotions. New York: Prentice-Hall.

Harre, R. M. (ur.) (1992). La costruzione sociale delle emozioni. Milano: Giuffre (prevod dela The Social Construction of Emotions. Oxford: Blackwell, 1986).

Legrenzi, P. (2002). Prime lezioni di scienze cognitive. Roma, Bari: Laterza.

Oliverio, A. (2001). La mente. Milano: Rizzoli.

Pasini, P. (2001). La diagnosi di "aiutante". Emozioni, corpi, storie in terapia familiare. Immagini di famiglie. Adultita, Milano: Guerini e Associati.

Plutchik, R. (1962). The Emotions: Facts, Theories and a New Model. New York: Random.

Plutchik, R. (1980). Emotion: A Psychoevolutionary Synthesis. New York: Harper\&Row.

Plutchik, R. (1995). Psicologia e biologia delle emozioni. Torino: Bollati Boringhieri.

Trevarthen, C. (1990). Le emozioni intuitive: l'evoluzione del loro ruolo nella comunicazione tra madre e bambino. V Ammaniti, M., Dazzi, N. (ur.) Affetti. Natura e sviluppo delle relazioni interpersonali. Roma, Bari; Laterza.

Trevi, M., Innamorati, M. (2000). Riprendere Jung. Torin. 